\title{
Evaluation of Embryotoxicity of Radix scutellariae Based on Embryonic Stem Test
}

\author{
Fenfang $\mathrm{Cao}^{1}$, Fen Chen ${ }^{1}$, Zhijian $\mathrm{Su}^{2}$, Linyan $\mathrm{Li}^{1}$, Aibo Huang ${ }^{1}$ and Hua $\mathrm{Xu}^{1 *}$ \\ ${ }^{1}$ College of Pharmacy, ${ }^{2}$ Department of Biopharmaceutical Research and Development Centre, Jinan University, Guangzhou \\ 510632, Guangdong, PR China \\ *For correspondence: Email: huax-mail@163.com; Tel: 86-020-38375022
}

\begin{abstract}
Purpose: To determine the potential embryotoxicity of Radix scutellariae (RS) extract using an embryonic stem cell test (EST) and to evaluate its effect on the differentiation of mouse embryonic stem (ES) cells.

Methods: All the test samples were obtained by water extraction method. The embryotoxicity of RS was assessed with cytotoxicity assays, namely, embryonic stem (ES) cells (IC $\left.{ }_{50} E S\right)$ and $3 T 3$ fibroblasts (IC $503 T 3)$, as well as cardiac differentiation inhibition assay (ID $50 E S)$. The expression of specific genes and proteins was analyzed by quantitative reverse transcription - polymerase chain reaction (RT-PCR) and Western blot.

Results: $R S$ was weakly embryotoxic with $I C_{50} E S$, IC $C_{50} 3 T 3$ and $I D_{50} E S$ of $0.1524,0.1061$, and 0.4169 $\mathrm{mg} / \mathrm{ml}$, respectively. Also RS had discordant effects on the expression of tissue-specific genes and proteins in three germ layers, promoting differentiation of the ectoderm $\left({ }^{\star} p<0.05\right.$; $\left.* \star p<0.01\right)$ and endoderm ( ${ }^{\star} p<0.05 ;{ }^{\star} p<0.01$; $\left.{ }^{\star \star \star} p<0.001\right)$, while inhibiting mesoderm differentiation $\left({ }^{\star} p<0.05\right.$; ${ }^{\star \star} p<$ $0.01 ; * \star \star p<0.001)$. The effect of $R S$ on the embryonic development of the three germ layers was concentration-dependent.

Conclusion: These results indicate that RS possesses weak embryotoxicity. The variability in the effects of RS may be responsible for its weak embryotoxicity.
\end{abstract}

Keywords: Embryonic stem test, Radix scutellariae, Embryotoxicity, Cardiac differentiation inhibition assay, Ectoderm, Endoderm, Mesoderm

Tropical Journal of Pharmaceutical Research is indexed by Science Citation Index (SciSearch), Scopus, International Pharmaceutical Abstract, Chemical Abstracts, Embase, Index Copernicus, EBSCO, African Index Medicus, JournalSeek, Journal Citation Reports/Science Edition, Directory of Open Access Journals (DOAJ), African Journal Online, Bioline International, Open-J-Gate and Pharmacy Abstracts

\section{INTRODUCTION}

Women are frequent users of natural herbs worldwide [1]. It is well known that some herbs have powerful pharmacological effects, and significant side effects have been reported in recent years. For instance, ginsenoside Rb1, a major active agent of ginseng, was shown to have direct teratogenic effects in a whole embryo culture assay [2]. It is vital that risks of herbal therapy to pregnant women, including traditional Chinese medicine (TCM), are evaluated $[3,4]$.
Radix scutellariae (RS), the dried root of Scutellariae baicalensis Georgi (labiatae), is commonly used in TCM to treat cardiovascular disease, inflammation, respiratory conditions, and gastrointestinal infections [5,6]. RS has additional therapeutic effects, such as preventing miscarriage [7]. Although RS is one of the most commonly used tocolytic agents, there has been little research on its toxicity [8]. 
In recent years, the embryonic stem test (EST) has become a widely used assay in the area of developmental toxicity $[9,10]$. The EST does not require experimental animals. The test is based on murine-derived embryonic stem (ES) cells from the blastocyst stage. Due to the pluripotency of ES cells, they differentiate in all lineages of the three germ layers: ectoderm, mesoderm, and endoderm [11]. The in vitro EST embryotoxicity assay requires a relatively simple procedure, which takes a shorter time than other assays used in developmental toxicological studies with experimental animals.

In the study we attempted to assess the embryotoxicity of RS using an EST and to analyze the expression levels of specific genes and proteins by quantitative RT-PCR and Western blot, respectively. The results are expected to shed light on the effects of RS on the three germ layers.

\section{EXPERIMENTAL}

\section{Test material}

RS was purchased from Mining Chi Lin Pharmacy of Guangzhou of China in July 2012 (produced in Anhui province, China; voucher no.05121802) and was authenticated by a specialist (Zhiguo Ma) in the Pharmacy of Jinan University. All the test samples were prepared by hot aqueous extraction. In brief, $100 \mathrm{~g}$ of the dried plant material RS were cut into small pieces and boiled in $1000 \mathrm{ml}$ of distilled water for $1 \mathrm{~h}$. The decoction was collected, while the residue was boiled again two times. The decoctions obtained from the three separate extractions were mixed, filtered, and lyophilized by freeze drying and then stored at $-20^{\circ} \mathrm{C}$. The dried extracts were dissolved in double-distilled water to give an initial concentration of $1 \mathrm{~g} / \mathrm{ml}$ and centrifuged at $14000 \mathrm{~g}$ for $5 \mathrm{~min}$ before filtration sterilization to obtain a clear, sterile supernatant for tests.

\section{T3 fibroblast and ES cell culture}

Mouse ES cells (line OG2, purchased from Guangzhou Institutes of Biomedicine and Health, Chinese Academy of Sciences) were maintained in Dulbecco's modified Eagles medium (DMEM), supplemented with $15 \%$ knockout serum replacement (KSR) (Gibco), $100 \mu \mathrm{gg}$ of streptomycin $/ \mathrm{ml}, 100 \mathrm{U}$ penicillin $/ \mathrm{ml}, 2 \mathrm{mM}$ of glutamine, $2 \mathrm{mM}$ of sodium pyruvate, $0.1 \% \beta$ merca-ptoethanol, $1 \%$ nonessential amino acids, and $1000 \mathrm{U}$ of leukemia inhibitory factor (LIF) $($ ESG1-06) $/ \mathrm{ml}$. All cell culture reagents were purchased from Sigma-Aldrich (MO, USA) unless otherwise stated. The ES cell medium was refreshed daily, and the cells were subcultured every $2-3$ days. A BALB/c 3T3 cell line was purchased from the cell bank of Zhongshan University of China. The BALB/c 3T3 cells were grown in DMEM, supplemented with $10 \%$ fetal calf serum (HyClone). The cells were cultured in $95 \%$ humidity and $5 \% \mathrm{CO}_{2}$ and at $37^{\circ} \mathrm{C}$.

\section{Cytotoxicity assay}

Followed the EST method as described previously [12], the cytotoxicity assay is a cell proliferation and tractviability test where the cells are exposed to a test compound. In brief, 500 cells were placed in each well of a 96-well tissue culture dish and incubated in a humidified atmosphere with $5 \% \mathrm{CO}_{2}$ at $37{ }^{\circ} \mathrm{C}$ on day 0 . Then, $200 \mu \mathrm{L}$ of a culture medium containing the appropriate dilution of RS extract was added on day 1 . On days 3 and 5 , the same test medium was changed. Cytotoxicity was assessed on day 10. Cell viability was determined with the CCK8 assay, which quantifies the proliferation and viability of cells by a colorimetric method. In short, at the indicated time points, the medium in different experimental wells was exchanged for $110 \mu \mathrm{l}$ of DMEM with CCK-8 reagent ( $10 \mu \mathrm{l} \mathrm{CCK-}$ 8 reagent and $100 \mu \mathrm{L}$ DMEM), and the cells were incubated for $2 \mathrm{~h}$. Absorbance was measured for each well at a wavelength of $450 \mathrm{~nm}$. An increase or decrease in absorbance values at $450 \mathrm{~nm}$ in different experimental wells relative to the initial value indicated cell viability [13]. The half-maximum inhibitory concentration of RS extracts on 3T3 cells and ES cell viability $\left(\mathrm{IC}_{50} 3 \mathrm{~T} 3\right.$ and $\left.\mathrm{IC}_{50} \mathrm{ES}\right)$ were obtained through a curve fit analysis (concentration-response curve) using the program GraphPad Prism 5.0 (San Diego, CA, USA) $[10,12]$.

\section{Differentiation assay}

To detect the effects of RS extract on ES cell differentiation, a differentiation assay was performed as described in detail previously $[14,15]$. In brief, 750 ES cells in $20 \mu \mathrm{L}$ of differentiation medium (without mouse LIF) were placed on the lid of a petri dish filled with PBS on day 0 . They were incubated for 2 days at $37^{\circ} \mathrm{C}$ under $5 \% \mathrm{CO}_{2}$ and $95 \%$ humidity in the presence of a concentration range of the test compound. The hanging drop culture method was used to produce cell aggregates referred to as embryoid bodies (EBs). The EBs was grown in suspension in bacterial petri dishes containing the appropriate concentration of test compound for another 3 days. On day 5 , the EBs were transferred singly into wells of a 6-well tissue 
culture plate (containing the appropriate concentration of test compound) to allow adherence and outgrowth of the EBs and development of spontaneously beating myocardial cells. On day 10 , the presence of the $\beta$-myosin heavy chain gene ( $\beta-\mathrm{MHC})$, which was used as a marker of cardiac cell differentiation, was determined by quantitative PCR. Inhibition of the differentiation $\left(\mathrm{ID}_{50}\right)$ of $\mathrm{ES}$ was expressed as the concentration of test compound inhibiting the development of contracting cardiomyocytes by $50 \%$ (calculated from the dose-response curve). The sequences of the primers used are listed in Table 1.

\section{Classification of the embryotoxic potential of RS}

ES cell lines and BALB/c 3T3 cells were used to assess the potential embryotoxicity of RS [16]. The $\quad I_{50}$ 3T3, IC $I C_{50}$ ES, and $I D_{50}$ ES embryotoxicity was assessed according to the classification criteria of the European Centre for the Validation of Alternative Methods (ECVAM) (Table 2). The embryotoxicity of test compounds is classified into three grades: nonembryotoxic (Class I), weakly embryotoxic (Class II), and strongly embryotoxic (Class III).
Analysis of differentiation of specific genes using RNA isolation, cDNA synthesis, and quantitative RT-PCR

Total RNA was extracted from the samples on day 10 of the differentiation assay using an E.Z.N.A.TM Total RNA Kit II (Omega, GA, USA). cDNA was synthesized with $1 \mu \mathrm{g}$ of RNA, and 4 $\mu \mathrm{L}$ of PrimeScript ${ }^{\mathrm{TM}} \mathrm{RT}$ Master Mix (Perfect Real Time; Takara, Shiga, Japan) in a total volume of $20 \mu \mathrm{L}$. The reaction system was subjected to 37 ${ }^{\circ} \mathrm{C}$ for $15 \mathrm{~min}$ for cDNA synthesis and $85^{\circ} \mathrm{C}$ for 5 $\mathrm{s}$ for enzyme inactivation.

Gene expression was detected by quantitative RT-PCR using a SoAdvanced ${ }^{\mathrm{TM}}$ SYBR ${ }^{\circledR}$ Green Supermix kit (Bio-Rad, CA, USA) in a final volume of $20 \mu \mathrm{L}$ based on the manufacturer's instructions. The reaction mixtures contained 1 $\mu \mathrm{L}$ of template cDNA with $100 \mathrm{nM}$ of forward and reverse primers and $10 \mu \mathrm{L}$ of SsoAdvanced ${ }^{\mathrm{TM}}$ SYBR $\circledast$ Green Supermix in a total volume of 20 $\mu \mathrm{L}$. Duplicate assays were run for each sample, and each included a negative control and a standard curve. Specific oligonucleotide primers were designed to produce 100-200 bp products.

Table 1: Primer sequences and product lengths of tissue-specific genes investigated

\begin{tabular}{|c|c|c|c|}
\hline \multirow{2}{*}{ Gene } & \multicolumn{2}{|c|}{ Primer sequence ( from 5' to 3') } & \multirow{2}{*}{$\begin{array}{c}\text { Product } \\
\text { length (bp) }\end{array}$} \\
\hline & Forward & Reverse & \\
\hline Oct-4 & GGTGGAGGAAGCCGACAAC & TTCGGGCACTTCAGAAACATG & 141 \\
\hline Sox-2 & AGATGCACAACTCGGAGATCAG & CCGCGGCCGGTATTTATAAT & 146 \\
\hline Naong & CTCAAGTCCTGAGGCTGACA & TGAAACCTGTCCTTGAGTGC & 120 \\
\hline GAPDH & GCCTTCTCCATGGTGGTGAA & GCACAGTCAAGGCCGAGAAT & 150 \\
\hline Nkx2.5 & CCATCCGTCTCGGCTTTGT & CCAAGTGCTCTCCTGCTTTCC & 148 \\
\hline MyoD & ACGGCTCTCTCTGCTCCTTTG & CGTGCTCCTCCGGTTTCA & 138 \\
\hline Tnni3 & ACCTGTCCACGTTCCGCAAG & CTTGTTGACGTGGGACTCGG & 100 \\
\hline$\beta-\mathrm{MHC}$ & GCCCTTTGACCTCAAGAAAG & CTTCACAGTCACCGTCTTGC & 156 \\
\hline ALB & CAGCAATGGCAGGCAGATC & GGAACTTGCCAAGTACATGTGTGA & 146 \\
\hline AFP & CAGCCATGAAGTGGATCACAC & GGAGGAATCTAACGTGGAAGCT & 126 \\
\hline TTR & GTCCTCTGATGGTCAAAGTC & TCCAGTTCTACTCTGTACAC & 193 \\
\hline GFAP & TGCCACGCTTCTCCTTGTCT & GCTAGCAAAGCGGTCATTGAG & 146 \\
\hline Nestin & CTGCAGGCCACTGAAAAGTT & TCTGACTCTGTAGACCCTGCTTC & 73 \\
\hline $\mathrm{NFH}$ & GCAGGAGGAGTGCGGCTAC & CCAACCTCACTCGGAACCACT & 224 \\
\hline
\end{tabular}

Table 2: ECVAM's validated prediction model of EST

\begin{tabular}{|c|c|c|}
\hline \multirow[t]{3}{*}{ A } & Function I & $5.9157 \mathrm{lg}\left(\mathrm{IC}_{50} 3 \mathrm{~T} 3\right)+3.500 \mathrm{lg}\left(\mathrm{IC}_{50} \mathrm{ES}\right)-\frac{5.307\left(\mathrm{IC}_{50} 3 \mathrm{~T} 3-\mathrm{ID} 50 \mathrm{ES}\right)}{\mathrm{IC}_{50} 3 \mathrm{~T} 3}-15.72$ \\
\hline & Function II & $3.6511 \lg \left(\mathrm{IC}_{50} 3 \mathrm{~T} 3\right)+2.3941 \lg \left(\mathrm{IC}_{50} \mathrm{ES}\right)-\frac{2.033\left(\mathrm{IC}_{503} \mathrm{~T} 3-\mathrm{ID} \mathrm{I}_{0} \mathrm{ES}\right)}{\mathrm{IC}_{50} 3 \mathrm{~T} 3}-6.85$ \\
\hline & Function III & $-0.125 \lg \left(\mathrm{IC}_{50} 3 \mathrm{~T} 3\right)-1.917 \mathrm{lg}\left(\mathrm{IC}_{50} \mathrm{ES}\right)+\frac{1.500\left(\mathrm{IC}_{50} 3 \mathrm{~T} 3-\mathrm{ID} 50 \mathrm{ES}\right)}{\mathrm{IC}_{50} 3 \mathrm{~T} 3}-2.67$ \\
\hline$B$ & $\begin{array}{l}\text { Class } 1 \\
\text { Class } 2 \\
\text { Class } 3\end{array}$ & $\begin{array}{cc}\text { Non-embryotoxic } & \text { If I }>\text { II and I > III } \\
\text { Weakly embryotoxic } & \text { If II }>\text { I and II }>\text { III } \\
\text { Strongly embryotoxic } & \text { If III }>\text { I and III }>\text { II }\end{array}$ \\
\hline
\end{tabular}

Linear functions discriminate Class I, II, and III and (B) embryotoxicity 
The amplification protocol was as follows: $30 \mathrm{~s}$ at $95^{\circ} \mathrm{C}$, then 40 cycles at $95{ }^{\circ} \mathrm{C}$ for $5 \mathrm{~s}$ and $60^{\circ} \mathrm{C}$ for $20 \mathrm{~s}$, followed by a melt curve at $65^{\circ} \mathrm{C}$ to 95 ${ }^{\circ} \mathrm{C}$ and an increment of $0.5{ }^{\circ} \mathrm{C}$ for $5 \mathrm{~s}$. Specific amplification was verified by the melt curve analysis. The relative quantitative expression of tissue-specific markers after normalization with the ubiquitously expressed GAPDH housekeeping gene was calculated. All the primer sequences are shown in Table 1.

\section{Western blot assay}

Western blot assays were performed to analyze the expression levels of tissue-specific protein makers. In brief, proteins were separated by $8 \%$ or $12 \%$ SDS-PAGE and transferred to PVDF membranes (Bio-Rad, CA, USA). The blotted membrane was blocked in TBST containing $5 \%$ non-fat milk for $1.5 \mathrm{~h}$ at room temperature. The primary antibody dilution was 1:1000 for afetoprotein (AFP) and neurofilament $\mathrm{H}$ (NFH) antibodies (CST, BSN, USA), and 1:800 for cardiac troponin I (cTnl) antibody (Merck Millipore, MA, USA). Antibody binding was detected with a secondary anti-antibody diluted at 1:2000 using a BM chemiluminiscence kit (Roche, IN, USA). Relative band intensity analysis was performed by densitometry scanning using Image $\mathrm{J}$ software. GAPDH was used as a cell fractionation control.

\section{Statistical analysis}

GraphPad Prism 5.0 (San Diego, CA, USA) was used for data plotting, non-linear regression, and statistical analysis. Data are given as the mean \pm SEM $(n=3)$. Data groups were compared using a

A

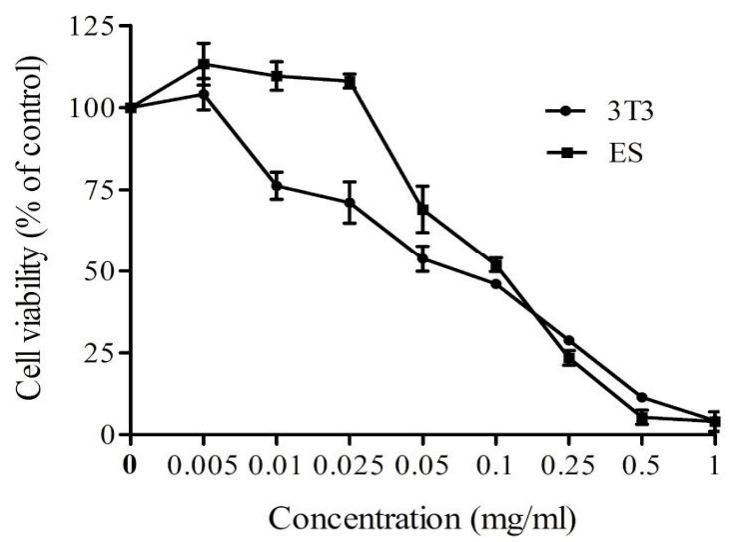

one-way ANOVA and Dunnett's multiple comparison post-test for more than two groups. Results were considered statistically significant at $p<0.05$.

\section{RESULTS}

\section{EST classification of RS}

\section{Cytotoxicity}

A cell viability assay was used to assess the cytotoxic effect of RS on the BALB/C 3T3 fibroblasts, representing adult tissues, and ES cells, representing embryonic tissues. In both cell lines, the RS extract inhibited the viability of cells, in a dose-dependent manner (Fig 1A). The IC50 value was $0.1061 \mathrm{mg} / \mathrm{ml}$ for the $3 T 3$ cells and $0.1524 \mathrm{mg} / \mathrm{ml}$ for the ES cells. The significant difference in the cytotoxic sensitivities of the two cell lines to RS indicates that the 3T3 cells are more sensitive to RS than the ES cells. RS extract stimulated the proliferation of the ES cells at low concentration levels.

\section{Differentiation inhibition}

Inhibition of cardiomyocyte differentiation was determined by quantitative expression analysis of the $\beta$-MHC gene (a marker of cardiac cell differentiation) normalized to GAPDH expression at day 10. The RS extract restrained cardiomyocyte differentiation of the ES cells in a dose-dependent manner (Fig 1B).

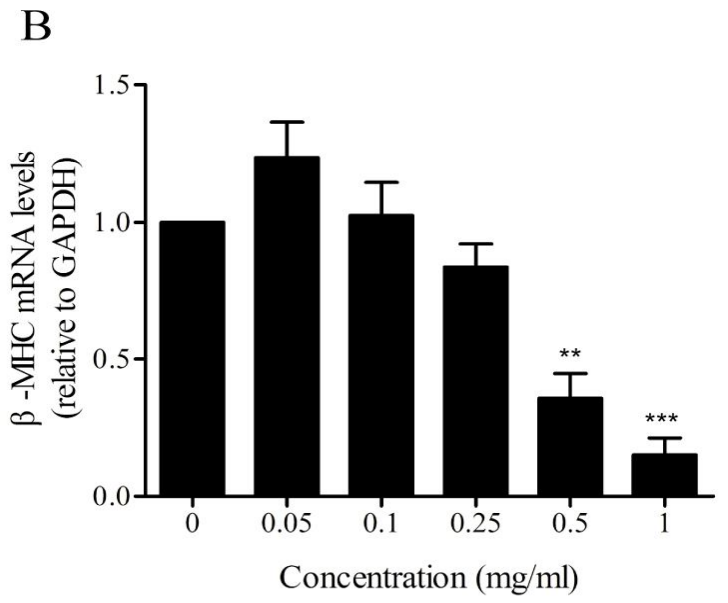

Figure 1: Cytotoxicity and differentiation assays of RS. (A) Cytotoxicity effects of RS on ES cells and BALB/C 3T3 cells. Values are mean \pm SEM $(n=3)$. Cell viability $(\%)=(\mathrm{OD}$ value of treated cells - OD value of blank control)/(OD value of control cells $-\mathrm{OD}$ value of blank control) $\times 100 \%$. Control cells refer to the cells untreated with RS. Values are means \pm SEM $(n=3)$; (B) Results of differentiation assays. Expression level of the $\beta-\mathrm{MHC}$ marker gene of cardiomyocytes normalized to GAPDH expression and analyzed by quantitative PCR 
As shown in Figure 1, RS stimulated cardiomyocyte differentiation of the ES cells at low concentrations and inhibited cardiomyocyte differentiation at high concentrations. The inhibiting effect became more evident as the concentrations increased. The $\mathrm{ID}_{50} \mathrm{ES}$ value was $0.4169 \mathrm{mg} / \mathrm{ml}$.

Based on these data and the ECVAM classification criteria (see Table 2), RS was classified as weakly embryotoxic.

Effect of RS on ES cell differentiation: undifferentiated specific markers

To assess the tissue-specific effects of RS (0 - 1 $\mathrm{mg} / \mathrm{ml}$ ) on ES differentiation at the molecular level, real-time quantitative PCR analysis of the expression levels of typical tissue-specific genes was performed on day 10 of the differentiation assay. The expression of Sox-2, Naong, and Oct-4 genes, markers of undifferentiated ES cells, all decreased first and then increased gradually in the presence of RS, with ES cell differentiation induced at a concentration range of $0-0.1 \mathrm{mg} / \mathrm{ml}$ and restrained at concentrations greater than $0.25 \mathrm{mg} / \mathrm{ml}$ (Fig 2A).

\section{Effect of RS on ES cell differentiation: ectodermal lineages}

The expression level of GFAP, an astrocytespecific marker, gradually increased at all concentrations, Nestin, a primitive neural stem cell marker, continued to increase in a dosedependent manner but precipitously declined at 1 $\mathrm{mg} / \mathrm{ml}$. NFH, a later-stage neuron-specific marker, increased first and then showed a decreasing trend (Fig 2B).
A
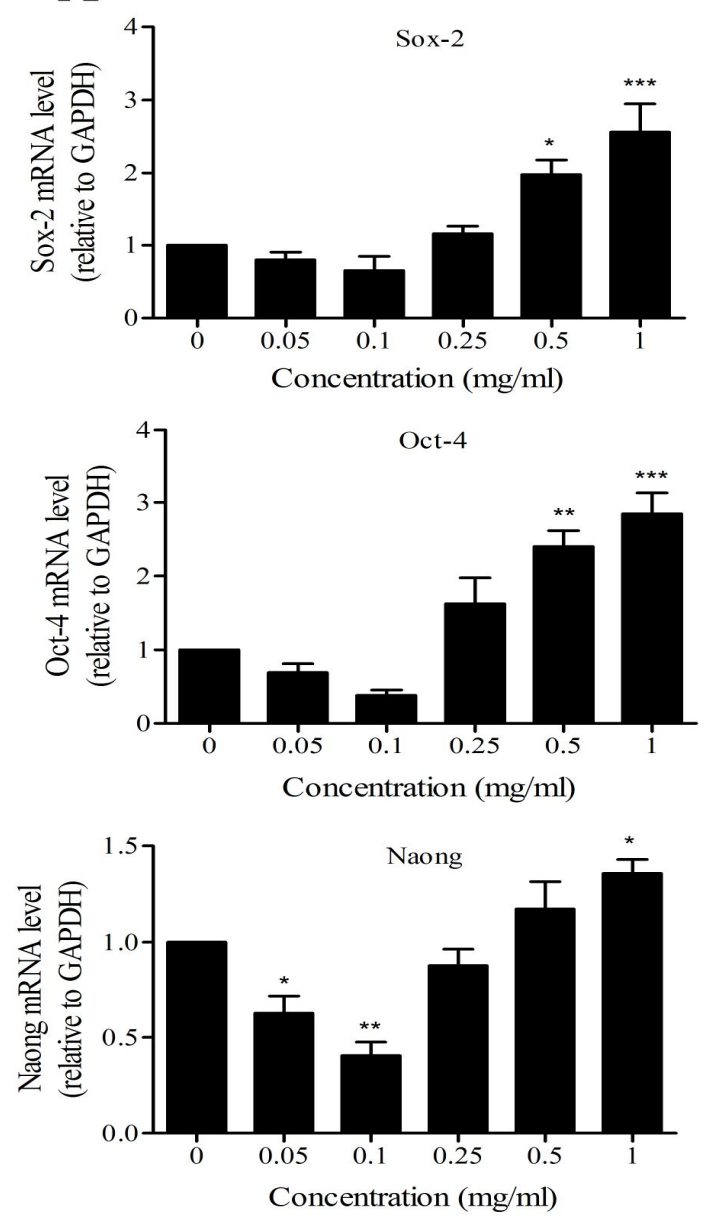

B
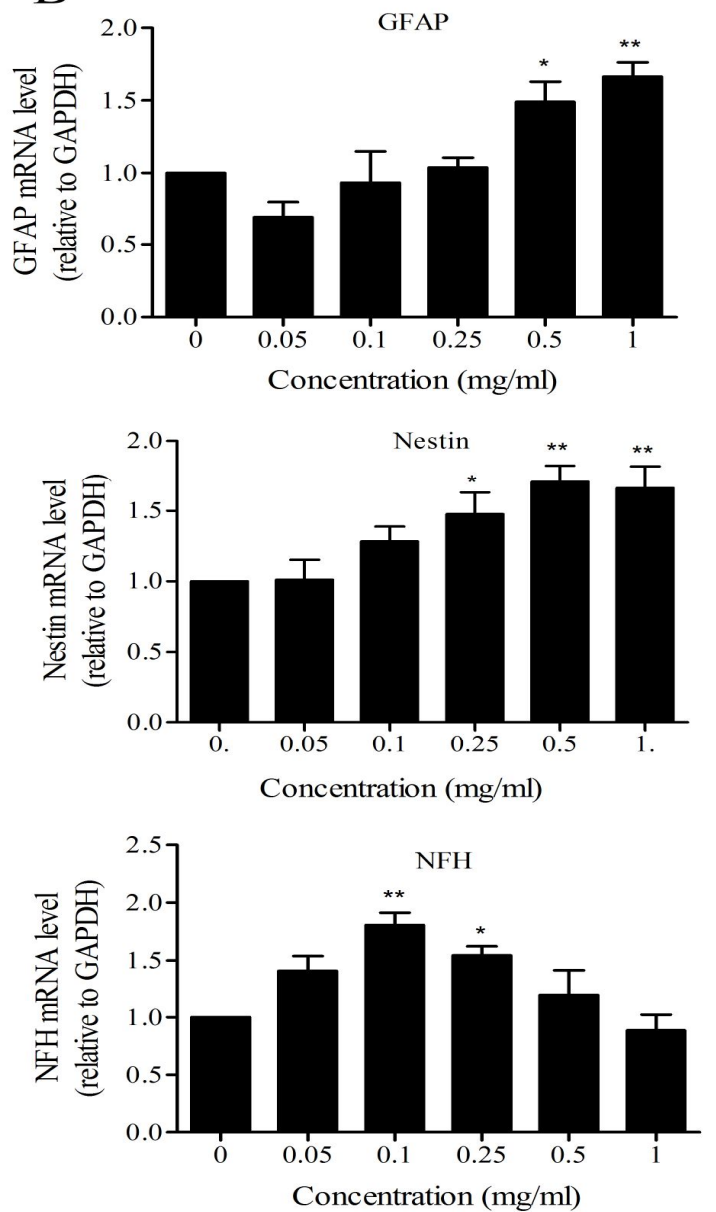

Figure 2: Analysis of expression levels of markers of undifferentiated ES cells and ectoderm differentiation. (A) Expression levels of the undifferentiated markers, Sox-2, Oct-4, and Naong; (B) Expression levels of the ectodermal markers GFAP, Nestin, and NFH. All the genes were quantified at appropriate concentrations of RS with real-time quantitative PCR. Values are mean $\pm \operatorname{SEM}(n=3)$. Comparisons with the control condition $(0$ $\mathrm{mg} / \mathrm{ml}) ;{ }^{\star} p<0.05 ;{ }^{\star \star} p<0.01 ;{ }^{\star \star \star} p<0.001$ 
Effects of RS on ES cell differentiation: mesodermal lineages

In the mesodermal lineage, the expression levels of Tnni3, a cardiac cell marker, and MyoD, a muscle cell marker, declined in a concentrationdependent manner. The expression level of $\mathrm{Nkx2.5}$, a late-stage marker, showed a slight increase at a concentration of $0.1 \mathrm{mg} / \mathrm{ml}$ but was slightly down-regulated at the other concentrations tested (Fig 3A).

\section{Effect of RS on ES cell differentiation: endodermal lineages}

The expression level of a marker of late differentiation stages, transthyretin (TTR), slightly increased at low concentrations of RS and rapidly decreased at high concentrations. The expression of albumin (ALB), a definitive endodermal hepatic marker, showed an increasing trend, but declined at the maximum

A
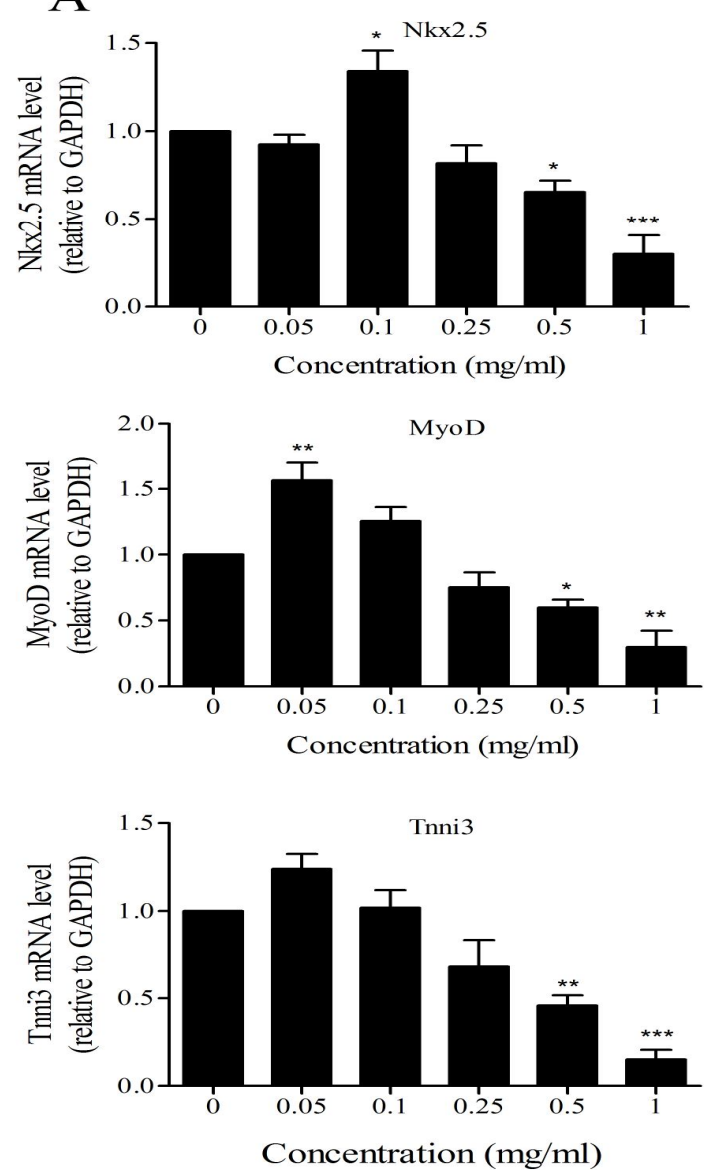

treatment concentrations. The expression of AFP increased gradually in a concentrationdependent manner (Fig 3B).

Effects of RS on the expression of AFP, cTnl, and NFH by Western blot analysis

The expression of AFP, cTnl, and NFH was assessed in ES cells treated with RS for 10 days to determine the effect of RS on ES cell differentiation in the ectoderm, mesoderm, and endoderm. Western blot analysis revealed that the protein expression level of AFP increased in accordance with a rise in the concentration of RS. However, the protein level of cTnl was effectively down-regulated by RS and not detected at an RS concentration of $1 \mathrm{mg} / \mathrm{ml}$. The expression of NFH slightly increased at low concentrations of RS, then decreasing gradually as the concentration increased (Fig 4).
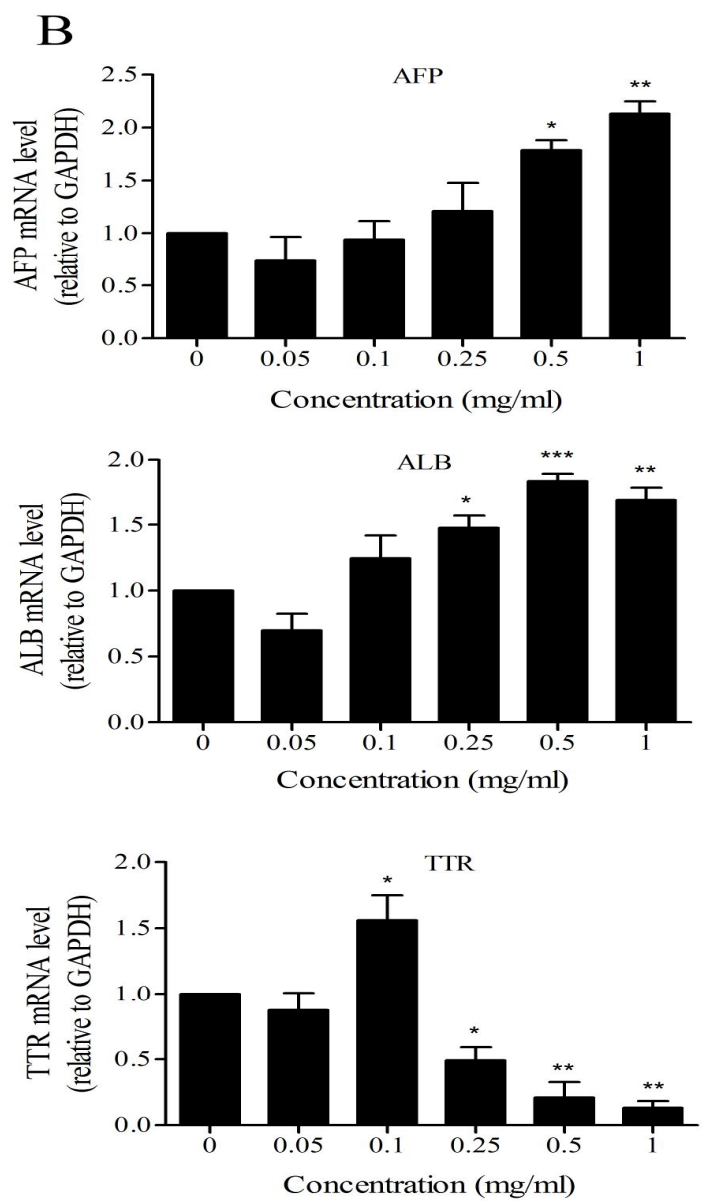

Figure 3: Analysis of expression levels for mesoderm and endoderm differentiation. (A) Expression levels of the mesodermal markers Nkx2.5, MyoD, and Tnni3; (B) Expression levels of the endodermal markers AFP, ALB, and TTR. All the genes were quantified at appropriate concentrations of RS with real-time quantitative PCR. Values are mean $\pm \operatorname{SEM}(n=3)$. Comparisons with the control condition $(0 \mathrm{mg} / \mathrm{ml}) ;{ }^{\star} p<0.05 ;{ }^{\star \star} p<0.01 ;{ }^{\star \star \star} p<0.001$ 
A
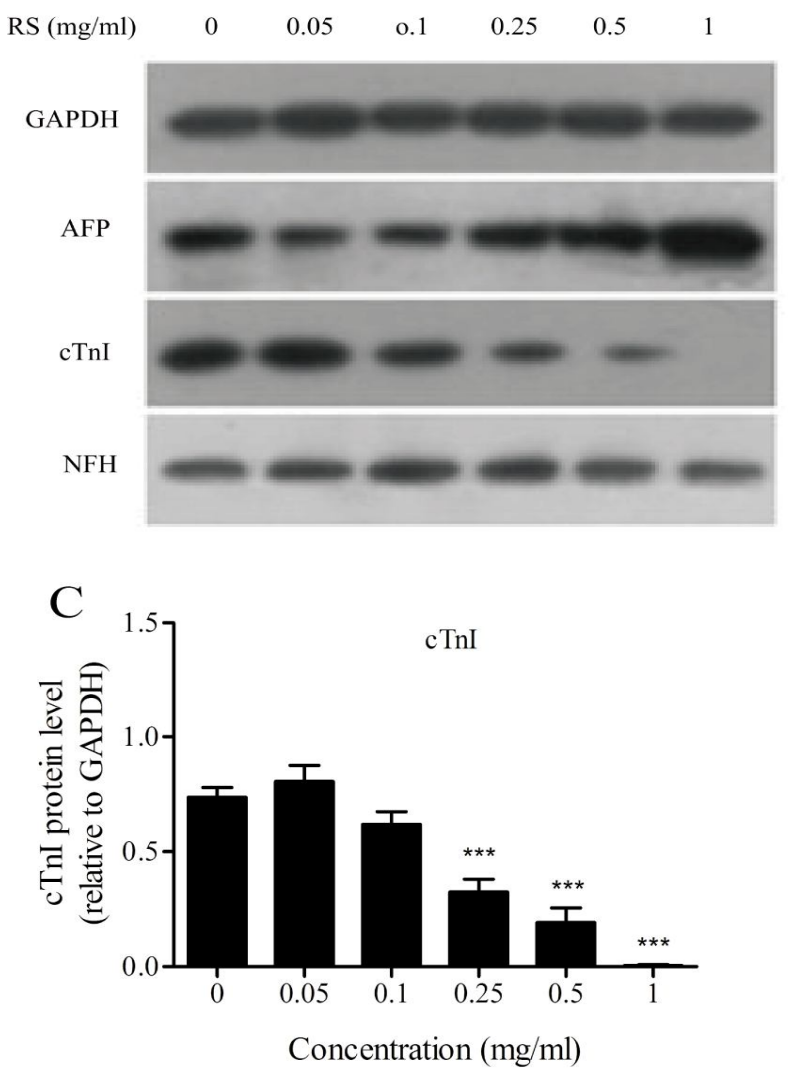

B
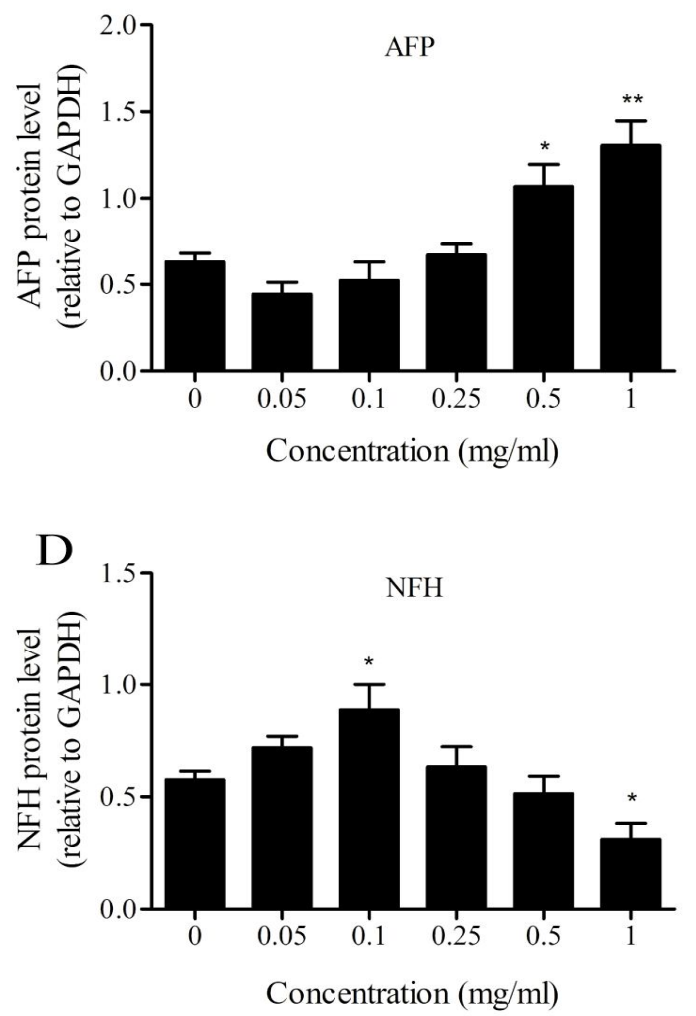

Figure 4: Western blot analysis of the expression of AFP, cTnl, and NFH after treatment with RS ( $n=3)$. Protein expression was assessed by quantitation of GAPDH.. Values are mean \pm SEM. Comparisons with the control condition $(0 \mathrm{mg} / \mathrm{ml}) ;{ }^{\star} p<0.05 ;{ }^{\star \star} p<0.01 ;{ }^{\star \star \star} p<0.001$

\section{DISCUSSION}

The ECVAM designed the EST as a tool for classifying the embryotoxicity compounds $[10,14]$. The $I_{50} 3 T 3$ value of a number of chemical compounds is higher than the $\mathrm{IC}_{50} \mathrm{ES}$ value $[17,18]$. In other words, ES cells, an embryonic tissue cell model, are more sensitive to the cytotoxic effect of compounds than 3T3 cells, an adult tissue cell model. However, in this study, we found that 3 T3 cells were more sensitive than ES cells to the cytotoxic effect of RS. In fact, the survival of ES cells was higher than that of $3 T 3$ cells at an RS concentration of $0.005-0.05 \mathrm{mg} / \mathrm{ml}$, and RS inhibited cell proliferation. Many reports have shown that some Chinese medicines can stimulate cell proliferation [19-22]. In the present study, the cytotoxic effect of RS was apparent at concentrations greater than $0.005-0.05 \mathrm{mg} / \mathrm{ml}$, indicating that it shows weak embryotoxicity. Therefore, we should consider the safety of RS in pregnant women.

To further evaluate the effects of RS on embryonic development, we selected specific molecular markers of the three germ layers and then assessed their expression following RS treatment. Interestingly, the RS extract has discordant effects on the expression of tissuespecific genes within the three germ layers. For example, the expression levels of ALB and AFP, endoderm-specific genes, were elevated at increasing concentrations of RS, suggesting that it promotes differentiation in endodermal lineages. In contrast, the expression of TTR decreased in a concentration-dependent manner, possibly because it is a sensitive gene. Further investigation is required to determine whether TTR can serve as a toxicity marker for RS.

In addition, the results showed that RS seemed to promote differentiation in ectodermal lineages, with the expression of the ectoderm-specific genes Nestin and GFAP increasing and reaching the highest level at an RS concentration of 1 $\mathrm{mg} / \mathrm{ml}$. Nestin, a marker of early nerve cell differentiation, displayed an upward trend, except at the highest concentration. The expression of the NHF gene and protein increased first and then decreased at $>0.25 \mathrm{mg} / \mathrm{ml}$. The expression levels of the mesoderm-specific markers MyoD and Tnni3 exhibited a downward trend at increased concentrations of RS, and Nkx2.5 was 
slightly down-regulated at high concentrations. These data indicate that RS may inhibit ES cell differentiation in myocardial cells. The Western blot analysis of the specific protein markers of the three germ layers (AFP, cTnl, and NFH) in the present study following $\mathrm{RS}$ treatment demonstrated that the expression of all the proteins was similar to that of their corresponding genes.

In summary, these findings suggest that RS exhibits a tendency to promote differentiation in ectodermal and endodermal lineages and inhibit differentiation in mesodermal lineages. Thus, RS may exert different effects on germ layer differentiation. Comprehensive analysis of the effects of different concentrations of RS on tissue-specific genes and proteins in the three germ layers is important to evaluate the embryotoxicity of RS.

The pharmacodynamic effects of medicinal plants are significantly associated with their phytochemical components, and analysis of their toxic ingredients is a key step in understanding their adverse effects and mechanisms. In general, agents used in TCM are taken in oral form. The composition of remedies used in TCM can be complex, and the way in which one TCM may interact with another is unknown. Thus, it is difficult to evaluate the side effects of herbs used in TCM. Here, the EST was employed to detect the toxicity of RS to ES cells and the effect of RS on differentiation. The EST model is appropriate since it cannot be constrained by the complexity of the chemical constituents of TCM $[8,23]$.

\section{CONCLUSION}

An in vitro EST has been used to characterize the embryotoxic effects of TCM, RS, and its effects on developmental processes in a mouse ES cell differentiation system. The results suggest that RS exhibits weak embryotoxicity based on assessment of $I_{50}$ and $I_{50}$ values. This study highlights the value of EST in identifying the potential developmental toxicity of herbal remedies at cellular levels. In vivo data and additional in vitro studies are needed to clarify the potential embryotoxicity of RS.

\section{ACKNOWLEDGEMENT}

The study was supported by the Guangdong Province Natural Science Foundation of China (Grant no. S2011010001898) and Guangdong Province Plan of Scientific and Technological Development.(Grant no. 2011B031700009).

\section{REFERENCES}

1. Gibson PS, Powrie R, Star J. Herbal and alternative medicine use during pregnancy: a cross-sectional survey (J). Obstetrics \& Gynecology, 2001; 97: S44S45.

2. Chan LY, Chiu PY, Lau TK. An in-vitro study of ginsenoside Rb1-induced teratogenicity using a whole rat embryo culture model. Human Reproduction, 2003; 18: 2166-2168.

3. Jordan SA, Cunningham DG, Marles RJ. Assessment of herbal medicinal products: challenges, and opportunities to increase the knowledge base for safety assessment. Toxicol Appl Pharmacol, 2010; 243: 198-216.

4. Wang CC, Li L, Tang LY, Leung PC. Safety evaluation of commonly used Chinese herbal medicines during pregnancy in mice. Hum Reprod, 2012; 27: 24482456.

5. Gong $X$, Sucher NJ. Stroke therapy in traditional Chinese medicine (TCM): prospects for drug discovery and development. Trends Pharmacol Sci, 1999; 20: 191 196.

6. Kang DG, Yun Ck, Lee HS. Screening and comparison of antioxidant activity of solvent extracts of herbal medicines used in Korea. Journal of Ethnopharmacology, 2003; 87: 231-236.

7. Li HB, Chen F. Isolation and purification of baicalein, wogonin and oroxylin A from the medicinal plant Scutellaria baicalensis by high-speed counter-current chromatography. J Chromatogr A 2005; 1074: 107110.

8. Kim MS, Ham SH, Kim JH, Shin JE, Oh J, Kim TW, Yun HI, Lim JH, Jang BS, Cho JH. Single-dose oral toxicity of fermented scutellariae radix extract in rats and dogs. Toxicol Res, 2012; 28: 263-268.

9. Tian $X Y, X u M$, Deng B, Leung KS, Cheng KF, Zhao ZZ, Zhang SP, Yang ZJ, Deng PX, Xu DY et al. The effects of Boehmeria nivea (L.) Gaud. on embryonic development: in vivo and in vitro studies. J Ethnopharmacol, 2011; 134: 393-398.

10. Seiler AE, Spielmann $H$. The validated embryonic stem cell test to predict embryotoxicity in vitro. Nat Protoc, 2011; 6: 961-978.

11. Keller G. Embryonic stem cell differentiation: emergence of a new era in biology and medicine. Genes \& Development, 2005; 19: 1129-1155.

12. Murabe M, Yamauchi J, Fujiwara Y, Hiroyama M, Sanbe A, Tanoue A. A novel embryotoxic estimation method of VPA using ES cells differentiation system. Biochemical and Biophysical Research Communications, 2007; 352: 164-169.

13. Zhou Y, Ling XL, Li SW, Li XQ, Yan B. Establishment of a human hepatoma multidrug resistant cell line in vitro. World J Gastroenterol, 2010; 16: 2291-2297.

14. Seiler AE, Buesen R, Visan A, Spielmann $H$. Use of murine embryonic stem cells in embryotoxicity 
assays: the embryonic stem cell test. Methods Mol Biol, 2006; 329: 371-395.

15. Scholz G, Genschow E, Pohl I, Bremer S, Paparella M, Raabe $H$, Southee J, Spielmann $H$. Prevalidation of the embryonic stem cell test (EST) - A new in vitro embryotoxicity test. Toxicology in Vitro, 1999; 13: 675-681.

16. Scholz G, Pohl I, Genschow E, Klemm M, Spielmann H. Embryotoxicity screening using embryonic stem cells in vitro: correlation to in vivo teratogenicity. Cells Tissues Organs, 1999; 165: 203-211.

17. Strikwold M, Woutersen RA, Spenkelink B, Punt A, Rietjens IM. Relative embryotoxic potency of $p$ substituted phenols in the embryonic stem cell test (EST) and comparison to their toxic potency in vivo and in the whole embryo culture (WEC) assay. Toxicol Lett, 2012; 213: 235-242.

18. Louisse J, Gonen S, Rietjens IM, Verwei M. Relative developmental toxicity potencies of retinoids in the embryonic stem cell test compared with their relative potencies in in vivo and two other in vitro assays for developmental toxicity. Toxicol Lett, 2011; 203: 1-8.
19. Lim JS, Yoo M, Kwon HJ, Kim H, Kwon YK. Wogonin induces differentiation and neurite outgrowth of neural precursor cells. Biochem Biophys Res Commun, 2010; 402: 42-47.

20. Yabe $T$, Hirahara $H$, Harada $N$, Ito $N$, Nagai $T$, Sanagi $T$, Yamada $H$. Ferulic acid induces neural progenitor cell proliferation in vitro and in vivo. Neuroscience, 2010; 165: $515-524$

21. Wang ZQ, Lou YJ. Proliferation-stimulating effects of icaritin and desmethylicaritin in MCF-7 cells [J]. Eur $\mathrm{J}$ Pharmacol. 2004;19; 504: 147-153.

22. Bohan Li SBY, Samir Jabaiti, Mi-Ae Sung, Soung-Min Kim, Myung-Jin Kim, Jeong Won Jahng, Zhihong Lin, Jong-Ho Lee. Traditional herbal medicines, Fuling, Baizhu, and Dangui promote the proliferation of human Schwann cells. Neural Regener Res 2010, 5: 1216-1219.

23. Xu M, Tian $X Y$, Leung $K S$, Lee $K C$, Chow TC, Deng B, Yiu CM, Chow Cl, Zhao ZZ, Yang ZJ et al. Embryotoxicity of Psoralea corylifolia L.: in vivo and in vitro studies. Birth Defects Res B Dev Reprod Toxicol, 2012; 95: 386-394. 